\title{
Potential Development of Chicken Egg Shell in Recycling of Waste Cooking Oil Innovation through the Stirer Chamber Device
}

\author{
Narwati Narwati (D), Hadi Suryono, Setiawan Setiawan* \\ Department of Environmental Health, Health Polytechnic of the Ministry of Health Surabaya, Surabaya, East Java, Indonesia
}

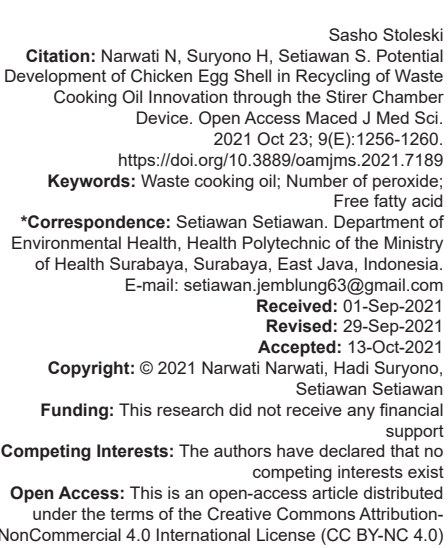

under the terms of the Creative Commons Attribution-

\begin{abstract}
BACKGROUND: Waste cooking oil (WCO) is overused for frying food can be a series of chemical changes, such as rancid, oxidation, and decomposition. Most of the secretion of toxic compounds are a product of oxidizing fatty acids, especially double-unsaturated fatty acids. The intervention of stirrer chamber unit and utilization of chicken egg's shell as an absorbent is known to be able to improve the quality of WCO, includes reducing the number of peroxide and the free fatty acids (FFA)

AIM: The purpose of this study was to analyze the effect of the powdered chicken egg's shell on the number of peroxide and the WCO's FFA through the stirrer chamber.

METHODS: The research design used a simple experiment type post-test only Control Group Design. The subject was divided randomly into two groups, the treatment was given to one group as a control group and another group (other treatment) as an experimental group. The WCO sample called "Jelantah" for each treatment was $100 \mathrm{ml}$ as much as 48 samples. The replication was carried out twice with 24 treatments of the mass of egg's shell powder that was $0 \mathrm{~g}$, $5 \mathrm{~g}, 10 \mathrm{~g}$, and $15 \mathrm{~g}$ at a stirring time for $15 \mathrm{~min}, 30 \mathrm{~min}$, and $45 \mathrm{~min}$ before and after heating $35^{\circ} \mathrm{C}$ using $150 \mathrm{rpm}$ of stirring speed. The sampling technique used purposive sampling and the data were analyzed by Anova statistical test. RESULTS: Based on the result from this research showed that the original WCO contained the number of peroxide and FFA exceeded the quality standard of SNI 3741 (2013) that is $16.7 \mathrm{MekO}_{2} / \mathrm{kg}$ and $0.69 \%$ in sequence. The average number of peroxide of control group before heating was $15.31 \mathrm{MekO}_{2} / \mathrm{kg}$ and after heating was 17.4 $\mathrm{MekO}_{2} / \mathrm{kg}$, while the FFA before heating was $0.61 \%$, and after heating was $0.71 \%$. The number of peroxide of the treatment group before heating was $12.83 \mathrm{MekO}_{2} / \mathrm{kg}$ and after heating was $6.98 \mathrm{MekO}_{2} / \mathrm{kg}$, while the FFA content before heating was $0.46 \%$ and after heating was $0.25 \%$.
\end{abstract}

CONCLUSION: It was concluded that chicken egg's shell powder could minimize the content of peroxide and WCO's FFA through the stirrer chamber.

\section{Introduction}

The use of used cooking oil for used cooking oil is still found in the community. Used cooking oil or waste cooking oil (WCO) in addition to providing other flavors in food, is also used to reduce production costs for business actors. Falade et al. [1] explained that in improving the properties of organic food, it is generally done by frying and burning methods using very high temperatures, so that possibility of thermal oxidation (Falade et al. 2017).

In the frying process, oil undergoes a degradation reaction due to heat, air and air, which eventually causes oxidation, hydrolysis, and polymerization. Suratno and Utomo [2] explained that the results of the degradation reaction in oil undergoing a thermal process can reduce the quality of cooking oil and have a bad impact on humans. (Suratno and Utomo, 2018) [2]. Falade et al. explained again that consuming thermally oxidized cooking oil has a negative effect on increasing lipid low-density lipoprotein, decreasing high-density lipoprotein and causing high cholesterol levels, changes in hemoglobin concentration, packed cell volume. Increases White Blood Cells, the number of neutrophils and lymphocytes, kidney function, and induces lipid peroxidation and oxidative stress which have degenerative pathogenesis (Falade et al. 2017).

Astuti's research showed that the peroxide value test results increased starting from the $3^{\text {rd }}$ repetition of frying on branded oil and the second repetition of bulk oil. The peroxide value obtained is higher than that required by SNI 3741 in 2013 which is $1.00 \mathrm{mg}$ O2/100g. Likewise, the results of the examination of free fatty acids (FFA) levels in bulk oil samples showed an increase after the $4^{\text {th }}$ repetition of frying, exceeding the oil quality requirements set by $\mathrm{SNI}$ (Max $0.30 \% \mathrm{w} / \mathrm{w}$ ) [3]. This explains that the high number of peroxides indicates that there has been damage to the cooking oil, which in turn will go rancid. Likewise, the increase in the number of FFA, which can be caused by the high water content, accelerates the hydrolysis of cooking oil. The presence of water in the oil will accelerate the hydrolysis process of cooking oil [4]. The research of Manurung et al. 2018 [13] showed an increase in peroxide number and FFA percentage after being treated by heating in 4 variations of time. The results indicate that the longer the cooking oil heating time, the higher the peroxide value and the percentage of FFA. The longer heating will cause the temperature of the cooking oil to increase. 
This results in the oxidation, hydrolysis, and polymerization of unsaturated fatty acids and results in the formation of ketones, aldehydes, and polymers. The description above becomes the mindset of researchers to carry out sustainability in the development of previous research with research orientation on the use of chicken eggshells as an adsorbent. Peng et al. [5] research explained that chicken eggshells can be used as a catalyst in converting calcium carbonate contained in chicken eggshells into calcium oxide through shell combustion (Peng et al., 2018). Calcined CaO is thought to have the ability to absorb FFA and color and to reduce the peroxide value of WCO oil. Analyzing the effect of chicken eggshell adsorbents on the peroxide number and FFA on the clarity of WCO through the Stirrer Chamber.

\section{Methods}

This research is a simple experimental research with Posttest Only Control Group Design approach. Subjects were randomly divided into two groups, treatment was given to one group as the control group and the other group (other treatments) as the experimental group. This design was carried out to determine the effect of stirring time, and the mass of chicken egg shells, both in the control group and the experimental group. The sample size is 48 samples with 24 treatments and 2 times of replication.

\section{Research stages}

\section{Sample preparation}

Filtering used cooking oil WCO with cheesecloth or filter paper to remove impurities in the form of solids or crumbs. After that, the content of peroxide number, FFA was analyzed.

\section{Adsorbent manufacturing}

Washing chicken eggshells as raw material for $\mathrm{CaCO}_{3}$ and removing the eggshell membrane. Wash the eggshells again with distilled water, drain and then dry at $105^{\circ} \mathrm{C}$ for $2 \mathrm{~h}$ in the oven. The dried eggshells were reduced in size with a mortar and then sieved using a 120 mesh sieve.

\section{Adsorbent activation}

Chicken eggshell powder that has been prepared, soaked in $0.1 \mathrm{M} \mathrm{HCl}$ solution for $48 \mathrm{~h}$, then drained, filtered, and washed with distilled water and aquabides until the $\mathrm{pH}$ is neutral $(\mathrm{pH}=7)$. After the $\mathrm{pH}$ was neutral, the adsorbent was recalcined at $500^{\circ} \mathrm{C}$ for $8 \mathrm{~h}$ (Haryono et al., 2018) [6].

\section{Adsorption process}

Weighing the adsorbent as much as $5 \mathrm{~g}, 10 \mathrm{~g}$ and $15 \mathrm{~g}$, respectively.

\section{Research stages}

1. Stage I: Making adsorbent

2. Phase II: Implementation of trials.

At this stage, the samples were divided into 24 groups with various adsorbent masses of $5 \mathrm{~g}, 10 \mathrm{~g}$ and $15 \mathrm{~g}$, stirring for $15 \mathrm{~min}, 30 \mathrm{~min}$ and $45 \mathrm{~min}$ before heating and after heating at $35^{\circ} \mathrm{C}$.

\section{Results and Discussion}

Examination of the decrease in WCO peroxide levels before and after heating between the control group and the treatment group obtained the following results:

Table 1 shows the highest percentage decrease in WCO peroxide levels in the CW3 code, namely the sample treated with the addition of $15 \mathrm{~g}$ of adsorbent with a stirring time of $45 \mathrm{~min}$, which is $79.97 \%$. The magnitude of the decrease in the highest peroxide value in the sample coded CW3 was used cooking oil which was treated with the addition of $15 \mathrm{~g}$ of adsorbent with a stirring time of $45 \mathrm{~min}$, which was $8.13 \mathrm{MekO}_{2} / \mathrm{Kg}$. This explanation can be shown in Figure 1 below:

Table 1: Recapitulation of Percentage Decrease in WCO Peroxide Number Based on Variations in Adsorbent Mass and Stirring Time

\begin{tabular}{llll}
\hline \multirow{2}{*}{ Sample Codeo } & \multicolumn{2}{l}{ Peroxide Number $\left(\mathrm{MekO}_{2} / \mathrm{kg}\right)$} & Decrease Percentage \\
\cline { 2 - 3 } & Before Warmup & After Warmup & \\
\hline $\mathrm{AW}_{1}$ & 15.15 & 11.215 & 25.97 \\
$\mathrm{BW}_{1}$ & 14.05 & 9.40 & 33.10 \\
$\mathrm{CW}_{1}$ & 13.165 & 7.20 & 45.31 \\
$\mathrm{AW}_{2}$ & 14.425 & 9.36 & 35.11 \\
$\mathrm{BW}_{2}$ & 13.26 & 7.67 & 42.16 \\
$\mathrm{CW}_{2}$ & 12.085 & 5.305 & 56.10 \\
$\mathrm{AW}_{3}$ & 12.155 & 6.28 & 48.33 \\
$\mathrm{BW}_{3}$ & 11.06 & 4.34 & 60.76 \\
$\mathrm{CW}_{3}$ & 10.16 & 2.035 & 79.97 \\
Amount & 115.51 & 62.805 & 426.81 \\
Average & 12.83 & 6.98 & 8.89 \\
\hline WCO: Waste cooking oil. & &
\end{tabular}

Free fatty acid levels also decreased before and after heating between groups treatment of groups control. This can be shown in Table 2 below:

Table 2: Recapitulation of Percentage Decrease in WCO FFA Levels Based on Variations in Adsorbent Mass and Stirring Time

\begin{tabular}{llll}
\hline Sample Code & FFA $(\%)$ & Decrease Percentage \\
\cline { 2 - 3 } & Before Warmup & After Warmup & \\
\hline AW $_{1}$ & 0.54 & 0.39 & 27.78 \\
$\mathrm{BW}_{1}$ & 0.515 & 0.34 & 33.98 \\
$\mathrm{CW}_{1}$ & 0.475 & 0.26 & 45.26 \\
$\mathrm{AW}_{2}$ & 0.56 & 0.355 & 35.71 \\
$\mathrm{BW}_{2}$ & 0.505 & 0.25 & 50.50 \\
$\mathrm{CW}_{2}$ & 0.375 & 0.23 & 38.67 \\
$\mathrm{AW}_{3}$ & 0.415 & 0.175 & 57.83 \\
$\mathrm{BW}_{3}$ & 0.37 & 0.145 & 60.81 \\
$\mathrm{CW}_{3}$ & 0.35 & 0.07 & 80.00 \\
Amount & 4.105 & 2.215 & 430.54 \\
Average & 0.46 & 0.25 & 0.08 \\
\hline WCO: Waste cooking oil, FFA: Free fatty acids. & &
\end{tabular}




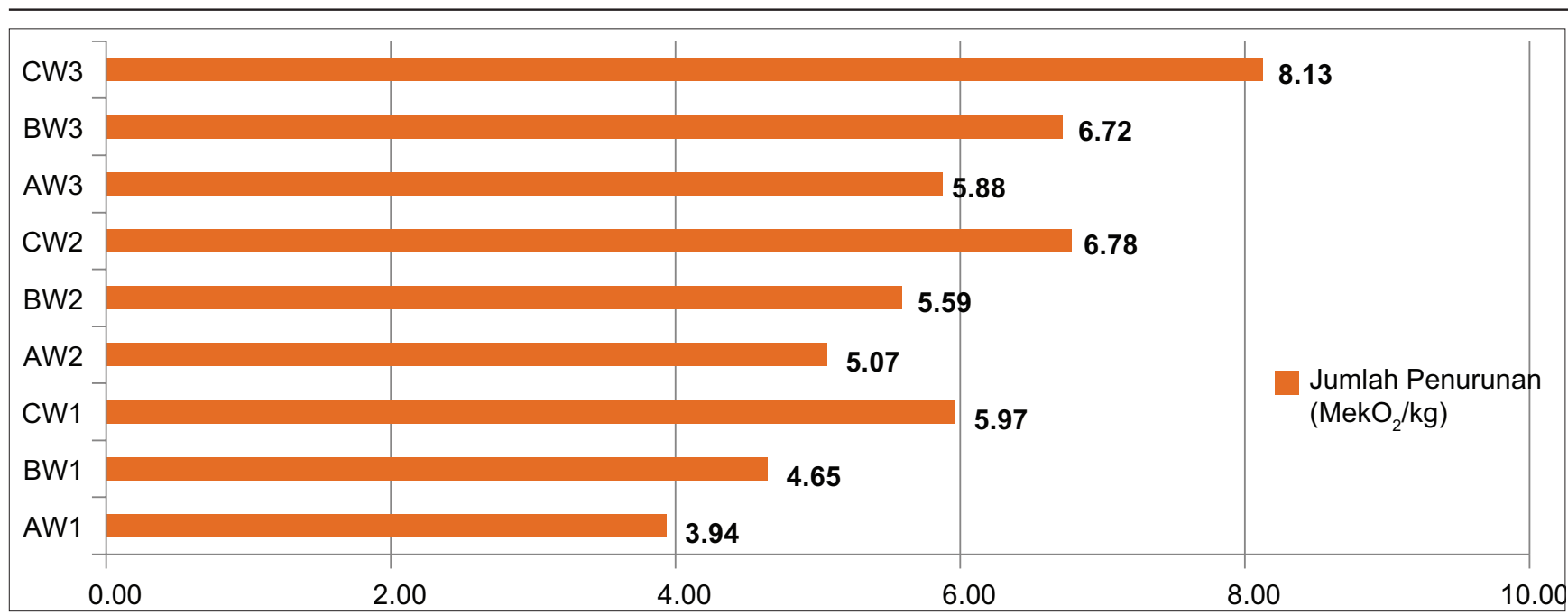

Figure 1: Graph of recapitulation of total decrease in levels waste cooking oil peroxide number by mass adsorbent and stirring time

Table 2 shows that the highest percentage reduction in WCO FFA levels was in the CW3 code, namely the sample treated with the addition of $15 \mathrm{~g}$ of adsorbent with a stirring time of $45 \mathrm{~min}$, which was $80.0 \%$. The magnitude of the decrease can be shown in Figure 2 below:

Figure 2 shows the highest decrease in WCO FFA levels in the CW3 coded sample, namely the sample treated with the addition of $15 \mathrm{~g}$ of adsorbent with a stirring time of $45 \mathrm{~min}$, which is $0.28 \%$. Based on the analysis of the Manova test using Pillai Trace, it is known that there is an effect or difference between heating temperature, adsorbent mass and stirring time on the levels of peroxides and FFA. The results of the analysis show that the calculated $\mathrm{F}$ value is 9934 with $\mathrm{p}=0.000<0.05$, so accept $\mathrm{H} 1$ which indicates a significant effect between treatments. The magnitude of the effect is $71.3 \%$. The levels of peroxide and FFA after the addition of the adsorbent mass of chicken eggshells after being given heating at $35^{\circ} \mathrm{C}$ and stirring, decreased below the threshold value of SNI 3741 of 2013 concerning cooking oil where the quality of cooking oil in terms of the maximum peroxide value of $10 \mathrm{MekO}_{2} / \mathrm{Kg}$ and FFA by $0.3 \%$. Cooking oil that undergoes repeated heating is known to undergo physical and chemical changes, namely changes in chemical reactions including hydrolysis, oxidation and polymerization reactions. The hydrolysis process can be shown in Figure 3.

Figure 4 explains that the breakdown of triglycerides involves the presence of hot water and steam from the frying process. The breakdown produces monoglycerides, diglycerides, FFA and glycerol. The degree of hydrolysis depends on and acid products arising from fat oxidation increase the hydrolysis process in the presence of steam during frying. The use of cooking oil continuously and repeatedly at high temperatures $\left(160-180^{\circ} \mathrm{C}\right)$ is accompanied by contact with air and water in the frying process. will result in a complex degradation reaction in oil and produce various reaction products. Cooking oil also changes color from yellow to dark. The degradation reaction products contained in WCO will also reduce the quality of fried foods and cause bad effects on health [7]. It was further explained that the damage to cooking oil that took place during frying and $220^{\circ} \mathrm{C}$ respectively. (Bhardwaj et al., 2016) [8] would also reduce the nutritional value and quality and value of fried food because it has the potential to cause an unattractive structure and appearance as well as an unpleasant taste and smell. Cooking oil that undergoes repeated heating is known to undergo physical and chemical changes. Nayak et al. [9] explained that the changes in chemical reactions include hydrolysis, oxidation and polymerization reactions. This research by Falade et al. (2017) strengthens the research of Venkata and Subramanyam which proves the hypothesis that heating vegetable oil to the boiling point results in the formation of free radicals that cause oxidative stress and cause damage at the cellular and molecular levels.

Another impact of repeated heating of oil causes changes in histopathology, antioxidant enzyme levels and blood biochemistry in experimental animals so that it has a detrimental effect on health. The peroxide value produced is higher than that of unheated oil.

Analysis of the levels of peroxide and FFA of "cooking" cooking oil WCO in this study showed that there was an effect of the mass of the adsorbent on chicken eggshells and the stirring time before heating at $35^{\circ} \mathrm{C}$ at a stirring speed of $150 \mathrm{rpm}$. The more mass of the adsorbent and the longer the stirring time in this study, the higher levels of peroxide and FFA decreased. The results showed that there were significant differences in the levels of peroxide and FFA in the treatment of adsorbent mass and stirring time at a stirring speed of $150 \mathrm{rpm}$ before and after 


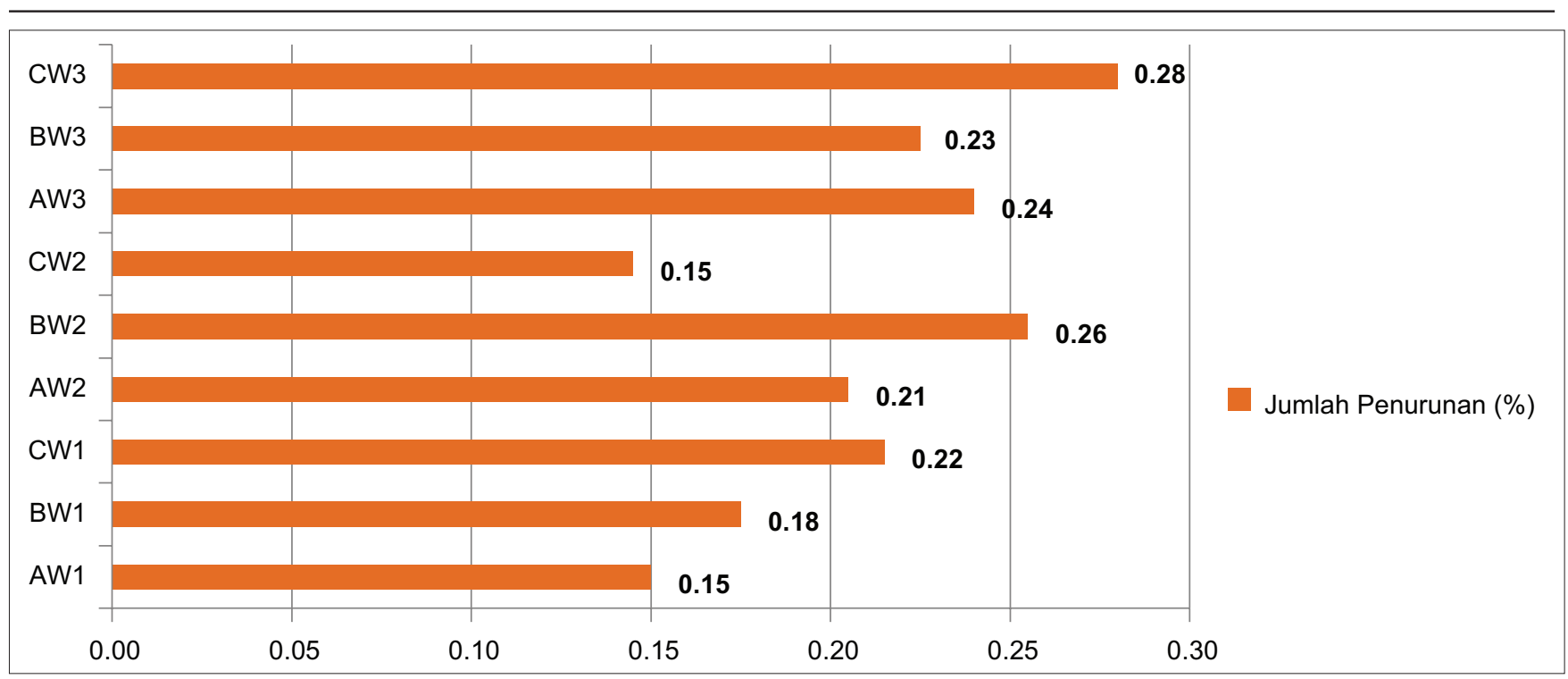

Figure 2: Graph of recapitulation of total decreased levels waste cooking oil free fatty acids by mass adsorbent and stirring time

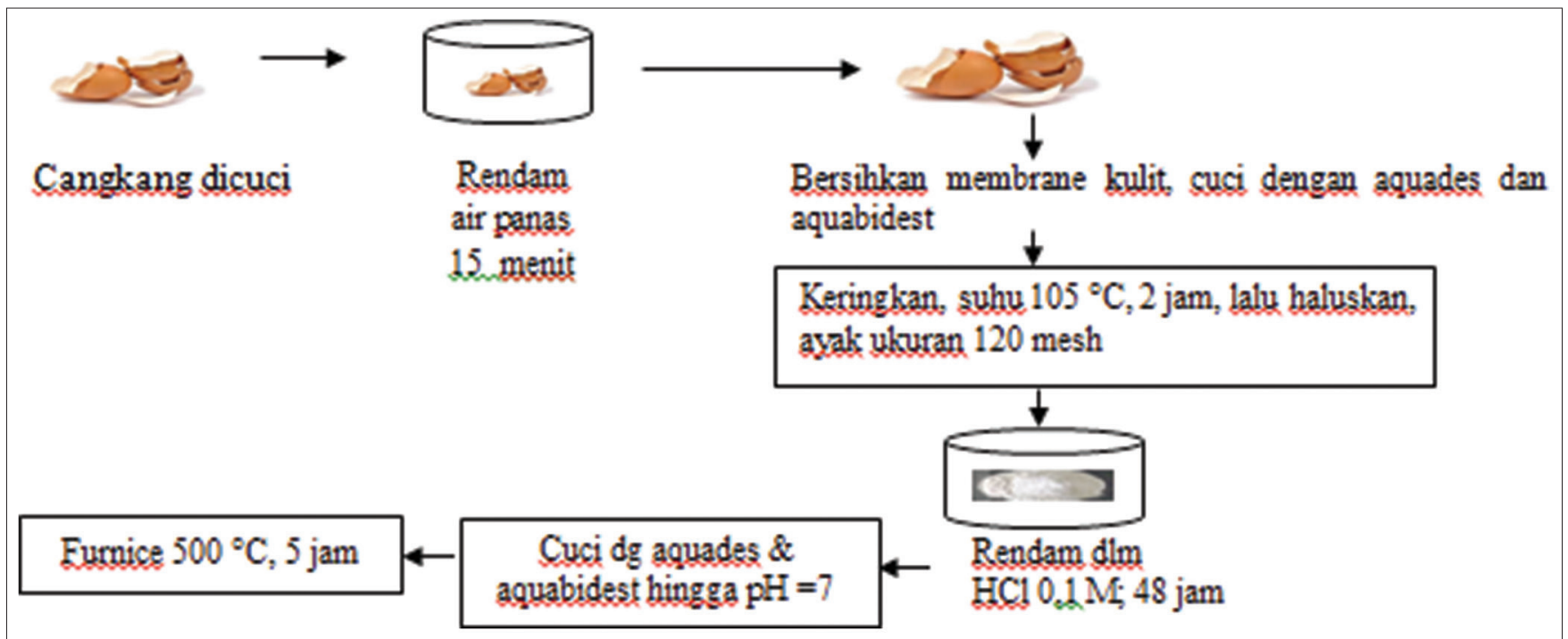

Figure 3: Stages of Making Adsorbent from Chicken Egg Shell

heating at a temperature of $35^{\circ} \mathrm{C}$. Research by Bhardwaj et al. proved that heated oil had an increase in saturated fatty acids. The increase in saturated fatty acid content in the oil undergoing heating or frying ranged from between $2.30 \pm 0.89 \mathrm{~g} / 100 \mathrm{~g}$ and $4.5 \pm 1.43 \mathrm{~g} / 100 \mathrm{~g}$ to $2.60 \pm 0.38 \mathrm{~g} / 100 \mathrm{~g}$ and $5.96 \pm$ $1.94 \mathrm{~g} / 100 \mathrm{~g}$ at $180^{\circ} \mathrm{C}$.

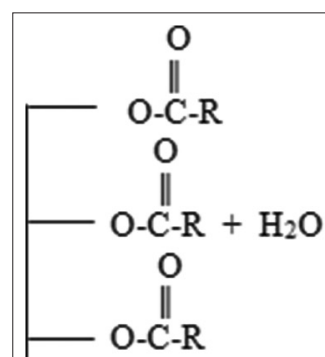

Triglyceride

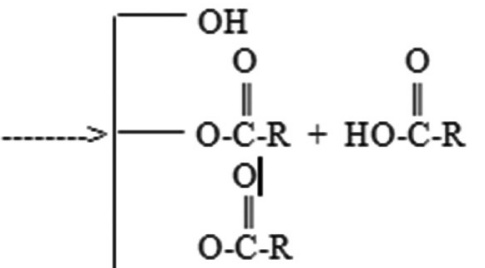

Diglyceride Fatty Acid
Figure 4: Formation of Diglyceride and Fatty Acids (Nayak et al., 2016)
Quoted from Fitriyana and Safitri [10], stirring time is one of the factors that affect the decrease in peroxide and FFA levels. It was further explained that the effectiveness of the adsorbent decreased in the adsorption process as the stirring time increased. This condition is caused by the occurrence of a saturation point on the adsorbent so that desorption occurs which can increase the content of the adsorbed substance. Fatty acid compounds are adsorbed on the active site of the chicken eggshell adsorbent.

The polar carboxyl end of the FFA has the potential to be adsorbed by the polar chicken eggshell powder (Fitriyana and Safitri, 2015) (2015).

In addition to stirring time, adsorbent mass plays a role in reducing the number of peroxides and FFA. It is known from the results of this study that the more mass of adsorbent used, the decrease in the number of peroxides and FFA was higher, namely at a 
mass of $15 \mathrm{~g}$ of adsorbent compared to the mass of $5 \mathrm{~g}$ and $10 \mathrm{~g}$ of adsorbent. This study also showed that the longer the stirring time and the greater the mass of the adsorbent, the levels of peroxide and FFA indicated that they were decreasing. The highest decrease was at a stirring time of 45 with a mass of $15 \mathrm{~g}$ of adsorbent. This study explains that the mass of the adsorbent and the stirring time together have a contribution in reducing the number of peroxides and FFA.

Fitriyana and Safitri explained that the peroxide containing oxygen is a polar compound which is more easily bound to polar adsorbents. It is known that activated chicken eggshell powder has the main component of polar calcium carbonate. The presence of stirring supports the strength of the interaction between the adsorbate and the adsorbate. This is based on the nature of the adsorbate and the adsorbent, one of which is the polarity of the adsorbent and adsorbate. It was also mentioned by Fitriyana and Safitri that if the adsorbent is polar, it will be bound more strongly than the less polar components. In addition, it was explained again that the adsorption power involves the van der Walls force where there is an attraction between molecules (Fitriyana and Safitri, 2015) [10].

It was clarified again by Tizo et al. [11] in their research that by increasing eggshell powder as an adsorbent, it greatly contributed to the increase in adsorption efficiency. The results showed that increasing the percentage of eggshell powder with increasing contact time, would increase the decrease in Cd levels [11].

It was stated that the presence of special functional groups from eggshell adsorbents such as hydroxyl, carboxyl and amide groups gave reinforcement to the adsorbent as a potential adsorbent so that $\mathrm{CaCO}_{3}$ contained an active site that binds the adsorbate (Tizo et al., 2018).

Schneider et al. [12] explained that stirring or adsorption kinetics indicates the speed at which molecules are adsorbed. The adsorption speed depends on the characteristics of the adsorbate, the adsorbent and the operating conditions provided, agitation (stirring), the temperature and mass of the adsorbent. In addition, stirring is responsible for particle dispersion, but promotes greater contact and mass transfer. The total adsorption time is related to the availability of active sites on the surface of the adsorbent. The maximum saturation of the adsorbent occurs when the surface is filled with solute. In most of the adsorption processes, it is known that there is a decrease in the amount of adsorbed substance with an increase in temperature due to the exothermic process (Schneider et al., 2019) [12].

\section{Conclusions and Recommendations}

Chicken egg shells can be used to minimize the number of peroxides and FFA. People are advised to avoid the use of used cooking oil and can use chicken egg shells in an effort to food safety.

\section{References}

1. Falade AO, Oboh G, Okoh Al. Potential health implications of the consumption of thermally-oxidized cooking oils a review. Pol J Food Nutr Sci. 2017;67(2):95-105. https://doi.org/10.1515/ pjfns-2016-0028

2. Suratno S, Utomo RV. Peroxide number in cooking oil for fried food sellers on Jalan Rajawali, Palangkaraya. Borneo J Med Lab Technol. 2018;1(1):25-9.

3. Astuti TD. Mirko, te molam vidi. Borneo J Med Lab Techno Technol 2018;1(1):25-9.

4. Lempang IR, Fatimawali, Pelealu NC. Test the quality of bulk cooking oil and packaged cooking oil in Manado. Pharmacon. 2016;5(4):13987. https://doi.org/10.35799/pha.5.2016.13987

5. Haryono H, Natanael CL, Rukiah R, Yulianti YB. Kalsium oksida mikropartikel dari cangkang telur sebagai katalis pada sintesis biodiesel dari minyak goreng bekas. J Mater Energi Indonesia. 2018;8:8-15.

6. Peng YP, Amesho KT, Chen CE, Jhang SR, Chou FC, Lin YC. Optimization of biodiesel production from waste cooking oil using waste eggshell as a base catalyst under a microwave heating system. Catalysts. 2018;8(2):81. https://doi.org/10.3390/ catal8020081

7. Sopianti DS, Herlina H, Saputra HT. Determination of free fatty acid levels in cooking oil. J Katalisator. 2017;2(2):100. https:// doi.org/10.22216/jk.v2i2.2408

8. Bhardwaj S, Passi SJ, Misra A, Pant KK, Anwar K, Pandey RM, et al. Effect of heating/reheating of fats/oils, as used by Asian Indians, on trans fatty acid formation. Food Chem. 2016;212:66370. https://doi.org/10.1016/j.foodchem.2016.06.021

PMid:27374582

9. Nayak PK, Dash U, Rayaguru K, Krishnan KR. Physio-chemical changes during repeated frying of cooked oil: A review. J Food Biochem. 2016;40(3):371-90. https://doi.org/10.1111/jfbc.12215

10. Fitriyana F, Safitri E. Utilization of chicken egg shells as an adsorbent to improve the quality of used cooking oil. Konversi. 2015;4(1):12-6. https://doi.org/10.20527/k.v4i1.260

11. Tizo MS, Blanco LA, Cagas AC, Cruz BR. Efficiency of calcium carbonate from eggshells as an adsorbent for cadmium removal in aqueous solution. Sustain Environ Res. 2018;28(6):326-32. https://doi.org/10.1016/j.serj.2018.09.002

12. Schneider LT, Bonassa G, Alves HJ, Meier TR, Frigo EP, Teleken JG. Use of rice husk in waste cooking oil pretreatment. Environ Technol (United Kingdom). 2019;40(5):594-604. https:// doi.org/10.1080/09593330.2017.1397772

13. Manurung M, Suwetja IK, Onibala H, Mentang F, Montolalu RI Storage Of Live Gold Fish Using Rice Husk Media Cooled. Jurnal Pengolahan Hasil Perikanan Indonesia. 2018 Apr 28;21(1):148-55. https://doi.org/10.17844/jphpi.v21i1.21538 